\title{
Comparison of the Basic Strength of Solid Catalysts in the Synthesis of 2-Styrylbenzoxazoles under Microwave, Ultrasonic Irradiations and Solvent Free Conditions
}

\author{
AZAR TAHGHIGHI ${ }^{1,}$, MAJID M. HERAVI $^{1}$ and FARZAD KOBARFARD ${ }^{2}$ \\ ${ }^{1}$ Department of Chemistry, School of Sciences, Azzahra University, Vanak, Tehran, Iran \\ ${ }^{2}$ Department of Medicinal Chemistry, School of Pharmacy, Shahid Beheshti University of \\ Medical Sciences, Tehran, Iran \\ atahghighi2009@gmail.com
}

Received 10 March 2013 / Accepted 30 April 2013

\begin{abstract}
Condensation of 2-methyl benzoxazole with aromatic aldehydes was carried out over a number of solid base catalysts under microwave, ultrasonic irradiation and solvent free conditions. $\mathrm{NaNH}_{2}$ supported on alumina in solvent free condition without microwave and ultrasound irradiation presented the most active base for the condensation.
\end{abstract}

Keywords: Heterogeneous catalysis, KF-alumina; CsNaX Zeolit, Microwave, Ultra Sound, 2-Styryl benzoxazoles

\section{Introduction}

2-Styryl benzoxazoles are prepared via condensation of 2-methylbenzoxazole with aromatic aldehydes in presence of different catalysts and methods ${ }^{1-2}$. These compounds have diverse biological activities such as antiviral ${ }^{3}$, antisecretory ${ }^{4}$ and different applications such as optical brightener ${ }^{5}$ and dyes ${ }^{6}$. Basic catalysts are suitable in synthesis of styryl benzoxazoles and considering the fact that replacing the liquid bases with solid base catalysts leads to cleaner reactions with high yield, high reaction rate, easy separation and purification of the products, utilization of such bases means saving in cost and energy. Therefore, such solid bases are frequently used in many chemical reactions. KF-alumina ${ }^{7}$, zeolites ${ }^{8}$ and $\mathrm{NaNH}_{2}-$ alumina $^{9}$ are efficient bases of this type.

$\mathrm{KF} /$ alumina was introduced by $\mathrm{Clark}^{7}$ and has been applied as catalyst to a variety of reactions and Ando and coworkers concluded that the fluoride ions and hydroxyl groups are the source of the strong basicity ${ }^{10}$. Advantage of the strongly basic nature of $\mathrm{KF} / \mathrm{Al}_{2} \mathrm{O}_{3}$, has allowed it to replace organic bases in a number of reactions including Suzuki couplings ${ }^{11}$, condensations $^{12}$, epoxidations ${ }^{13}$, diazetizations ${ }^{14}$, Sonogashira couplings ${ }^{15}$, Knoevenagel reactions ${ }^{16}$ and etc. 
The catalytic activities of basic zeolites have been also reported also in early 1970s by yashima et $\mathrm{al}^{17}$ and they have concluded that oxygen ions in the zeolite framework are responsible for weak basic effect of this catalyst. In alkali ion-exchanged zeolites, the basic strength was added and controlled by selecting the exchanged cation and the type of zeolite ${ }^{8,17-18}$. The high activities are caused by the generation of strong basic sites by addition of alkali ions which are located in the zeolite cavities in the form of alkali oxides. Today, zeolite X has many applications for a high ion exchange capacity and large pore size which make this zeolite as a high-cation exchange material ${ }^{19}$. The post-synthesis modification of $\mathrm{NaX}$ zeolite is carried out by conventional ion-exchange technique, using $5 \mathrm{wt} . \%$ of aqueous solutions of chloride salts of $\mathrm{K}, \mathrm{Rb}$ and $\mathrm{Cs}$. The basicity of $\mathrm{NaX}$ zeolite is added from $\mathrm{Na}$ to $\mathrm{Cs}$ (as a non framework cations) directly reflecting on the extent of basicity of cations. The zeolites are used in many reactions such as Knoevenagel reactions ${ }^{20}$, condensations ${ }^{21}$ and Henry reactions ${ }^{22}$.

Alkali amides present excellent bases in organic synthesis and Alkali amides supported on alumina have led to the emergence of very effective solid base catalysts that have been used in many reactions such as alken isomeration ${ }^{23-24}$, vinyl byciclohepten isomerization ${ }^{24}$ and Dimerization ${ }^{24}$.

On the other hand, the application of microwave ${ }^{25}$ and ultra sonic irradiations ${ }^{26}$ in reactions using heterogeneous catalysts or supports especially in solvent-free conditions is a promising method due to the short reaction times, purer products, minimized waste and good yields. Herein we have reported the application of $\mathrm{KF}$-alumina and $\mathrm{CsNaX}$ zeolite in synthesis of 2-styryl benzoxazoles under microwave oven and ultrasound conditions in presence of solvents and in solvent-free conditions and also $\mathrm{NaNH}_{2}$ supported on alumina and $\mathrm{NaX}$ zeolite in solvent-free conditions (Scheme 1).

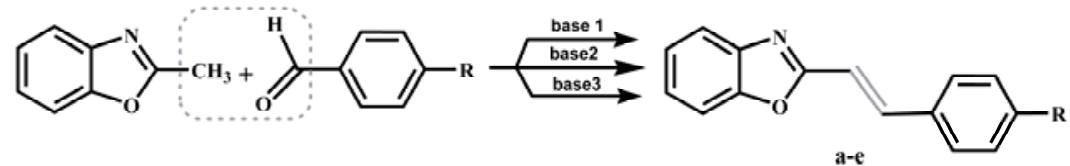

a: $\mathrm{R}=\mathrm{H}, \mathrm{b}: \mathrm{R}=\mathrm{Cl}, \mathrm{c}: \mathrm{R}=\mathrm{CH} 3$, d: $\mathrm{R}=\mathrm{OCH}_{3}$, e: $\mathrm{R}=\mathrm{N}\left(\mathrm{CH}_{3}\right)_{2}$

Scheme 1. Base 1: KF/alumina, base 2: CsNaX zeolite, base 3: $\mathrm{NaNH}_{2}$

\section{Experimental}

All commercially available chemicals were purchased from Merck and Aldrich Company and used as received. Melting points were measured using Barnstead Electro thermal. Ultrasonic apparatus was POWER SONIC 405. The microwave oven used, was LG MOD MC-838 WR.

\section{Chemistry}

The condensation of 2-methylbenzoxazole (1) with substituted benzaldehyes (2) has been carried out in the presence of $\mathrm{KF} / \mathrm{Al}_{2} \mathrm{O}_{3}, \mathrm{CsNaX}$ zeolite under microwave and ultrasound irradiations in solvent free and solvent conditions and $\mathrm{NaNH}_{2}$ supported on alumina and $\mathrm{NaX}$ zeolite (Scheme 1). The products were obtained in good yield and identified by comparison of their physical and spectroscopic data with those reported in literature ${ }^{1-2}$. The results are summarized in Table 1.

\section{General procedures for the preparation of 2-styryl benzoxazoles using KF-basic alumina}

A mixture of aqueous solution of $\mathrm{KF}\left(0.6 \mathrm{~g}, 10 \mathrm{mmole} \mathrm{KF}\right.$ in $\left.10 \mathrm{~mL} \mathrm{H}_{2} \mathrm{O}\right)$ and basic alumina $(1 \mathrm{~g})$ was stirred at room temperature for $30 \mathrm{~min}$. The mixture was then concentrated to dryness under vacuum and kept at $150{ }^{\circ} \mathrm{C}$ for $30 \mathrm{~min}$. This mixture was transferred to a 
pestle and DMSO or DMF (2 mmole) and 2-methyl benzoxazole (1 mmole, $0.13 \mathrm{~mL})$ were added and the mixture was well ground for $5 \mathrm{~min}$. Finally, aldehyde (1.05 mmole) was added to the mixture and ground for $2 \mathrm{~min}$. The mixture was then exposed to microwave irradiation $(600 \mathrm{~W})$ or ultrasonic irradiation. After completion of the reaction, the mixture was cooled down and extracted with $15 \mathrm{~mL}$ acetone or ethyl acetate. After filtration of the solid support and removal of the solvent the product was purified by recrystallization from ethanol/ $\mathrm{H}_{2} \mathrm{O}$. The mechanism is shown in scheme 2 .<smiles>[R]c1ccc(/C=C/c2nc3ccccc3o2)cc1</smiles>

Scheme 2. The mechanism of condensation of 2-methylbenzoxazole with aromatic aldehydes in presence of KF-basic alumina

\section{General procedures for the Preparation of 2-styryl benzoxazoles using zeolite}

$\mathrm{NaX}$ Zeolite was prepared hydrothermally from $\mathrm{Na}_{2} \mathrm{O}, \mathrm{SiO}_{2}, \mathrm{Al}_{2} \mathrm{O}_{3}$ and $\mathrm{H}_{2} \mathrm{O}$, according to the literature ${ }^{27-28}$. The $\mathrm{CsNaX}$ was prepared conventionally by ion exchange of $\mathrm{NaX}$ powder with 5 wt. $\%$ cesium chloride solution at $100{ }^{\circ} \mathrm{C}$ for $12 \mathrm{~h}$. The aqueous salt solution was taken in the proportion of $15 \mathrm{~mL} \mathrm{~g}^{-1}$ of zeolite for exchange reaction. The solid was filtered by vacuum system and washed with distilled water to remove chloride ions. The solid was again dried in an air oven maintained at $100{ }^{\circ} \mathrm{C}$ for $10 \mathrm{~h}$ and stored for later use. The CsNaX zeolite $(1 \mathrm{~g})$ was transferred to a pestle and DMSO or DMF (2 mmole) and 2-methyl benzoxazole $(1 \mathrm{mmole}, 0.13 \mathrm{~mL})$ were added. The mixture was then ground for $5 \mathrm{~min}$. Finally, aldehyde ( $1.05 \mathrm{mmole}$ ) was added to the mixture and was ground again for $2 \mathrm{~min}$. The mixture was then exposed microwave irradiation or ultrasonic irradiation. After completion of the reaction, the products were isolated and purified according to the method mentioned above. The mechanism is shown in Scheme 3.

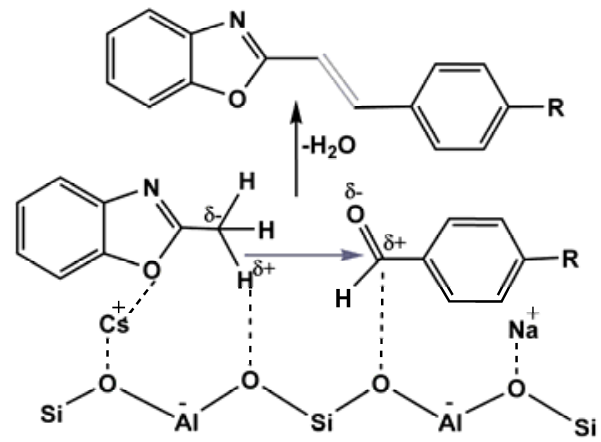

Scheme 3. The mechanism of condensation of 2-methylbenzoxazole with aromatic aldehydes in presence of $\mathrm{CsNaX}$ zeolite 
Chem Sci Trans., 2014, 3(1), 55-60

General procedures for the preparation of 2-styryl benzoxazoles using $\mathrm{NaNH}_{2}$ supported on alumina or $\mathrm{NaX}$ zeolite

2-Methyl benzoxazole $(1 \mathrm{mmole}, 0.13 \mathrm{~mL})$ and basic alumina or $\mathrm{NaX}$ zeolite support $(1 \mathrm{~g})$ was transferred to a pestle and well was ground using a mortar for $5 \mathrm{~min}$. Sodium amide $(0.19$ g, 5 mmole) was then added under inert atmosphere $\left(\mathrm{N}_{2}\right)$ and ground and the aldehyde $(1.05$ mmole) was immediately added and the mixture was ground again about 30-40 second until the color of mixture is completely changed. After completion of the reaction, the compounds obtained by this method were isolated and purified according to the procedure mentioned.

\section{Results and Discussion}

Condensation of 2-methyl benzoxazole with aromatic aldehydes has been facilitated with $\mathrm{KF} / \mathrm{Al}_{2} \mathrm{O}_{3}$ and $\mathrm{NaX}$ zeolite in conjunction with microwave and ultrasound under various conditions in presence of DMSO or DMF and in solvent free condition. Also, $\mathrm{NaNH}_{2}$ supported on alumina and $\mathrm{NaX}$ zeolite were used as the heterogeneous bases. The results are summarized in Table 1.

Table 1. The comparison of yield and reaction time for the synthesis of 2-styryl benzoxazoles in different conditions

\begin{tabular}{|c|c|c|c|c|c|c|c|c|c|c|c|c|c|c|}
\hline \multirow[b]{2}{*}{$\overline{\mathrm{Com}}$} & \multicolumn{6}{|c|}{$\begin{array}{c}\text { KF-basic alumina / Microwave } \\
\text { irradiation }\end{array}$} & \multicolumn{6}{|c|}{$\begin{array}{l}\text { KF-basic alumina / Ultrasound } \\
\text { irradiation }\end{array}$} & \multicolumn{2}{|c|}{$\begin{array}{l}\mathrm{NaNH}_{2-}^{-} \\
\text {basic } \\
\text { alumina }\end{array}$} \\
\hline & $\begin{array}{c}\text { React } \\
\text { ion } \\
\text { time } \\
(\mathrm{s})\end{array}$ & $\begin{array}{c}\text { Yield } \\
\% \\
\text { DMS } \\
\text { O }\end{array}$ & $\begin{array}{l}\text { React } \\
\text { ion } \\
\text { time } \\
(\mathrm{s})\end{array}$ & $\begin{array}{c}\text { Yield } \\
\% \\
\text { DMF }\end{array}$ & $\begin{array}{c}\text { React } \\
\text { ion } \\
\text { time } \\
(\mathrm{s})\end{array}$ & $\begin{array}{l}\text { Yield } \\
\% \\
(\mathrm{sf})^{\mathrm{a}}\end{array}$ & $\begin{array}{c}\text { React } \\
\text { ion } \\
\text { time, } \\
\text { min }\end{array}$ & $\begin{array}{c}\text { Yield } \\
\% \\
\text { DMS } \\
\text { O }\end{array}$ & $\begin{array}{c}\text { React } \\
\text { ion } \\
\text { time } \\
\text { min }\end{array}$ & $\begin{array}{c}\text { Yield } \\
\% \\
\text { DMF }\end{array}$ & $\begin{array}{c}\text { React } \\
\text { ion } \\
\text { time } \\
\text { min }\end{array}$ & $\begin{array}{l}\text { Yield } \\
\% \\
(\mathrm{sf})\end{array}$ & $\begin{array}{l}\text { React } \\
\text { ion } \\
\text { time } \\
(\mathrm{s})\end{array}$ & $\begin{array}{l}\text { Yield } \\
\% \\
(\mathrm{sf})^{\mathrm{a}}\end{array}$ \\
\hline $\mathrm{a}$ & 40 & 88 & 150 & 82 & 360 & 62 & 20 & 68 & 20 & 68 & 55 & 50 & 30 & 90 \\
\hline b & 40 & 90 & 150 & 83 & 360 & 65 & 20 & 68 & 20 & 70 & 55 & 50 & 30 & 91 \\
\hline $\mathrm{c}$ & 45 & 92 & 170 & 88 & 480 & 70 & 20 & 71 & 25 & 70 & 60 & 55 & 35 & 95 \\
\hline$d$ & 45 & 92 & 170 & 85 & 480 & 65 & 20 & 69 & 25 & 67 & 60 & 46 & 35 & 92 \\
\hline e & 45 & 87 & 182 & 82 & 480 & 68 & 25 & 65 & 30 & 65 & 60 & 46 & 35 & 90 \\
\hline & & $\mathrm{NaX}$ & $\begin{array}{r}\text { zeolite } \\
\text { irradi }\end{array}$ & $\begin{array}{l}\text { es / Mi } \\
\text { iation }\end{array}$ & crowa & & & $\mathrm{sNaX}$ & $\begin{array}{r}\text { zeolite } \\
\text { irradi }\end{array}$ & $\begin{array}{l}\text { es / Ul } \\
\text { iation }\end{array}$ & Itrasour & & $\begin{array}{r}\mathrm{NaN} \\
\mathrm{NaXz}\end{array}$ & $\begin{array}{l}\mathrm{JH}_{2-} \\
\text { eolite }\end{array}$ \\
\hline$\overline{\text { Comp }}$ & $\begin{array}{c}\text { React } \\
\text { ion } \\
\text { time } \\
(\mathrm{s})\end{array}$ & $\begin{array}{c}\text { Yield } \\
\% \\
\text { DMS } \\
\text { O }\end{array}$ & $\begin{array}{l}\text { React } \\
\text { ion } \\
\text { time } \\
(\mathrm{s})\end{array}$ & $\begin{array}{c}\text { Yield } \\
\% \\
\text { DMF } \\
\end{array}$ & $\begin{array}{c}\text { React } \\
\text { ion } \\
\text { time } \\
(\mathrm{s})\end{array}$ & $\begin{array}{l}\text { Yield } \\
\% \\
(\mathrm{sf})^{\mathrm{a}}\end{array}$ & $\begin{array}{c}\text { React } \\
\text { ion } \\
\text { time, } \\
\text { min }\end{array}$ & $\begin{array}{c}\text { Yield } \\
\% \\
\text { DMS } \\
\text { O }\end{array}$ & $\begin{array}{c}\text { React } \\
\text { ion } \\
\text { time } \\
\text { min }\end{array}$ & $\begin{array}{c}\text { Yield } \\
\% \\
\text { DMF }\end{array}$ & $\begin{array}{c}\text { React } \\
\text { ion } \\
\text { time } \\
\text { min }\end{array}$ & $\begin{array}{l}\text { Yield } \\
\% \\
(\mathrm{sf})\end{array}$ & $\begin{array}{l}\text { React } \\
\text { ion } \\
\text { time } \\
\text { (s) }\end{array}$ & $\begin{array}{c}\text { Yield } \\
\% \\
(\mathrm{sf})^{\mathrm{a}}\end{array}$ \\
\hline $\mathrm{a}$ & 120 & 71 & 200 & 69 & 600 & 50 & 25 & 59 & 30 & 60 & 70 & 35 & 35 & 86 \\
\hline $\mathrm{b}$ & 120 & 78 & 200 & 73 & 600 & 52 & 25 & 63 & 30 & 61 & 70 & 35 & 35 & 88 \\
\hline c & 180 & 75 & 250 & 75 & 700 & 52 & 30 & 64 & 30 & 65 & 80 & 33 & 40 & 89 \\
\hline $\mathrm{d}$ & 180 & 78 & 250 & 75 & 700 & 49 & 30 & 60 & 35 & 60 & 80 & 37 & 40 & 86 \\
\hline $\mathrm{e}$ & 200 & 75 & 280 & 69 & 700 & 45 & 35 & 60 & 35 & 55 & 80 & 32 & 40 & 85 \\
\hline
\end{tabular}

As Table 1 shows, the application of microwave irradiation in addition to $\mathrm{KF} / \mathrm{Al}_{2} \mathrm{O}_{3}$ provides higher yield and shorter reaction time compared to $\mathrm{CsNaX}$ zeolite and under ultrasonic irradiation. On the other hand, $\mathrm{KF} / \mathrm{Al}_{2} \mathrm{O}_{3}$ under microwave irradiation in presence of DMSO gave the best results which could be due to the utilization of microwave irradiation power and DMSO as polar solvent. The main absorption occurs between microwaves and the polar molecules of the solvent and energy transfer occur from solvent to 
reaction mixture and the reactants ${ }^{29}$. Whereas the lowest results obtained under solvent free conditions in the presence of $\mathrm{KF} / \mathrm{Al}_{2} \mathrm{O}_{3}$ and $\mathrm{CsNaX}$ zeolite. It is apparent that under ultrasound condition the reaction is completed in longer period of time indicating that the ultrasound irradiation has less power than microwave irradiation in this reaction.

The reactions carried out in solvent free conditions are considered more environmentally friendly. Tow solvent-free reactions were carried out using $\mathrm{NaNH}_{2}$ loaded on alumina and $\mathrm{NaX}$ zeolite presented good results. Both of these reactions were easy to conduct and took place in a short time, without the need to use microwave or ultrasound irradiation. The reaction could be further explored in other condensation reactions such as aldol and Michael addition.

In conclusion, condensation of 2-methyl benzoxazole with aromatic aldehydes was carried out over a number of solid base catalysts under microwave, ultrasonic irradiation and solvent free conditions. $\mathrm{NaNH}_{2}$ supported on alumina in solvent free condition without microwave and ultrasound irradiation presented the most active base for the condensation.

\section{Acknowledgment}

The authors are thankful to Azzahra University Research Council for the partial financial support.

\section{References}

1. Sun J, Yan C G and Han Y, Synth Commun., 2001, 31(1), 151-154; DOI:10.1081/SCC-100000192.

2. $\quad$ Dryanska V and Ivanov C, Tetrahedron Lett., 1975, 41, 3519;

DOI: 10.1016/S0040-4039(00)91356-X

3. Houpis I N, Molina A, Lynch J, Reamer R A, Volante R P and Reider P J, J Org Chem., 1993, 58(11), 3176-3178; DOI:10.1021/jo00063a047.

4. $\quad$ Press J B and Sanfilippo P, US Patent 4861897, 1989.

5. Schinzel E, Main F, Pintschovius U, Taunus K, Lebkucher H and Taunus H. US Patent 3674781, 1972.

6. Fayed T A, Safaa El-Din Etaiw H and Khatab H M, J Photochem Photobiol A: Chem., 2005, 170(1), 97-103; DOI:10.1016/j.jphotochem.2004.08.006.

7. Clark J H, Chem Rev., 1980, 80, 429-452; DOI:10.1021/cr60327a004.

8. $\quad$ Ono Y and Baba T, Catal Today, 1997, 38(3), 321-337;

DOI:10.1016/S0920-5861(97)81502-5.

9. Handa H, Fu Y, Baba T and Ono Y, Catal Lett., 1999, 59(2-4), 195-200; DOI:10.1023/A:1019093126342.

10. Ando T, Stud Surf Sci Catal., 1994, 90, 9-20; DOI:10.1016/S0167-2991(08)61795-4.

11. Kabalka G W, Pagni R M and Hair C M, Org Lett., 1999, 1(9), 1423-1425; DOI:10.1021/o1990972f.

12. Lopez J, Jacquot R and Figueras F, Stud Surf Sci Catal A, 2000, 130, 491-496; DOI:10.1016/S0167-2991(00)81005-8.

13. Fraile J M, Garcia J I, Matoral J A and Figueras F, Tetrahedron Lett., 1996, 37(33), 5995-5996; DOI:10.1016/0040-4039(96)01257-9.

14. Alloum A B and Villemin D, Synth Commun., 1989, 19(13-14), 2567-2571; DOI:10.1080/00397918908052657.

15. Kabalka G W, Wang L, Namboodiri V and Pagni R M, Tetrahedron Lett., 2000, 41(27), 5151-5154; DOI:10.1016/S0040-4039(00)00774-7.

16. Clark J H and Macquarrie D J, Org Proc Res Dev., 1997, 1(2), 149-162;

DOI:10.1021/op960008m. 
17. Yashima T, Yamazaki K, Ahmad H, Katsuta M and Hara N, J Catal., 1970, 17(2), 151-156; DOI:10.1016/0021-9517(70)90088-6.

18. Zhang X, Man Lai E S, Martin-Aranda R and Yeung K L, Appl Catal A: Gen., 2004, 261(1), 109-118; DOI:10.1016/j.apcata.2003.10.045.

19. Traa Y and Thompson R W, J Mater Chem., 2002, 12, 496-499; DOI:10.1039/B108634K,.

20. Wang Q L, Ma Y D and Zuo B, Synth Commun., 1997, 27(23), 4107-4110; DOI:10.1080/00397919708005458.

21. Holderich W F, Stud Surf Sci Catal., 1989, 46, 193-209;

DOI:10.1016/S0167-2991(08)60977-5.

22. Handa H, Baba T, Yamada H, Takahashi T and Ono Y, Catal Lett., 1997, 44(1-2), 119-121; DOI:10.1023/A:1018952320020.

23. Baba T, Handa H and Ono Y, J Chem Soc Faraday Trans., 1994, 90, 187-191; DOI:10.1039/FT9949000187.

24. Baba T, Kato A, Handa H and Ono Y, Catal Lett., 1997, 47(1), 77-80; DOI:10.1023/A:1019011811727.

25. Lidstrom P, Tierney J, Wathey B and Westman J, Tetrahedron, 2001, 57(45), 92259283; DOI:10.1016/S0040-4020(01)00906-1.

26. Bonrath W, Ultrason Sonochem., 2003, 10(2), 55-59;

DOI:10.1016/S1350-4177(02)00154-2.

27. Bondareva G V, Rat'ko A I and Azarov S M, Inorg Mater., 2003, 39(6), 605-609; DOI:10.1023/A:1024053304236.

28. Joshi U D, Joshi P N, Tamhankar S S, Joshi V V, Rode C V and Shiralkar V P, Appl Catal A: Gen., 2003, 239(1-2), 209-220; DOI:10.1016/S0926-860X(02)00391-5.

29. Loupy A, Perreux L, Liagre M, Burle K and Moneuse M, Pure Appl Chem., 2001, 73(1), 161-166; DOI:10.1351/pac200173010161. 